\title{
Streven naar volwaardig burgerschap voor iedereen
}

\author{
Het verhaal van coöperatie Heerlen STAND-BY!
}

\author{
Nancy Wijnen
}

Published online: 5 November 2018

(C) Bohn Stafleu van Loghum is een imprint van Springer Media B.V., onderdeel van Springer Nature 2018

\begin{abstract}
Een stoere keuze noemt directeur Elvira van Bergen de keuze van de gemeente om de coöperatie Heerlen STAND-BY! volledig verantwoordelijk te maken voor de uitvoering van de ondersteuning binnen het sociale domein. Dit betekent dat de gemeente Heerlen geen afzonderlijke organisaties heeft gecontracteerd, maar kiest voor een samenwerkingsverband dat de vrijheid krijgt om zelf de uitvoering van ondersteuning te regelen. Gedachte hierachter is dat niet gekeken wordt naar welke organisatie een bepaalde vorm van ondersteuning kan bieden, maar dat uitgegaan wordt van de hulpvraag van de cliënt. Heerlen STAND-BY! is een jong samenwerkingsverband van grote en kleinere welzijnsen zorginstanties en onderaannemers. Daardoor is er volop tijd om te investeren in het hulpverleningsproces in plaats van deels bezig te zijn met concurrentie. Er wordt één doel nagestreefd: het realiseren van volwaardig burgerschap voor iedere inwoner van Heerlen. Aan de hand van verhalen van directeur Elvira van Bergen, een medewerker en cliënten van Heerlen Stand-By! een beschrijving van de werkwijze van deze coöperatie.
\end{abstract}

\section{Het ontstaan}

Precies drie jaar geleden is het zaadje geplant. Een zestal zorg- en welzijnsorganisaties in Heerlen vindt dat er geld verspild wordt, niet alleen door de aanbestedingen, maar ook doordat ze langs elkaar heen werken. Het moet en kan anders, vinden ze. Een overtuiging die gedeeld wordt door de gemeente Heerlen. Vlak voor de zomer van 2016 wordt een pilot opgestart in Hoensbroek. Enkele maanden later al schrijft een enthousiaste gemeente Heerlen een Europese aanbesteding uit voor de hele gemeente. Begin

N. Wijnen ( $\bowtie)$

PITTIG in de media, Maastricht, Nederland

nancy@pittigmedia.nl december 2016 wordt een handtekening onder een zevenjarig contract gezet en op 1 januari 2017 gaat Heerlen STAND-BY! van start.

\section{Vernieuwende werkwijze}

In de beginperiode gaat de coöperatie vooral beheersmatig aan de slag. De winkel is gewoon open. Alle cliënten moeten een heronderzoek aangeboden krijgen, terwijl intern alle procedures rondom de werkwijze nog verder uitgedacht moeten worden. De Wmo is een nieuwe taak voor de coöperatie en daardoor gaat er in het begin veel tijd zitten in het reguleren van klantstromen. Tegelijkertijd moeten medewerkers al aan de slag met een nieuwe werkwijze - ze moeten met elkaar samenwerken, whitelabel werken (werken zonder rugnummer van de organisaties) en in dialoog met de inwoners om te komen tot passende ondersteuning, in plaats van een beschikking invullen. Voor medewerkers én partnerorganisaties is dat best lastig, want medewerkers vallen tegelijkertijd onder de hiërarchische leiding van hun moederorganisatie en onder de functionele leiding van de coöperatie. De moederorganisaties zorgen voor het hele HR-stuk en voor het behoud van vakinhoudelijke kennis (specifieke knowhow en 'knowwhat'). De coöperatie zorgt voor de dagelijkse aansturing, taakverdeling en coaching. Tegenover de inzet van medewerkers, methoden, instrumenten, gebouwen, ICT-oplossingen, enzovoort, staat een lumpsumbedrag. Dat wil zeggen dat de coöperatie een vooraf gecalculeerd bedrag aan de moederorganisaties geeft, in ruil voor hun inbreng.

'We zijn in het begin heel wat keren over de kop gegaan omdat iets niet blijkt te werken', vertelt Elvira van Bergen, 'maar het mooie aan onze coöperatie is dat we heel wendbaar zijn en dat maakt dat we kunnen presteren. We zijn niet gebonden aan regels en organisato- 
rische plichten. We kunnen ons volledig concentreren op het ondersteuningsproces.'

Dat ondersteuningsproces is dus heel anders ingericht. Weg zijn de beschikkingen waarin staat welke hulp voor hoeveel uur toebedeeld is. Heerlen STAND$\mathrm{BY}$ ! is een algemene voorziening. De medewerkers van de coöperatie zijn continu met de cliënt in dialoog. Zij moeten zich voortdurend afvragen of ze het goede doen met en voor de cliënt. Daarnaast moeten medewerkers hun eigen agenda beheren en dat is lastig. Directeur Elvira van Bergen: 'Ben je na drie kwartier klaar, dan ga je door naar de volgende. Voorheen maakte je gewoon de tijd vol en dat gaf ruimte voor meer pauzes. Het is hard werken en continu op een hoog niveau presteren. Dat is de keerzijde van ons werk.'

\section{Investeren in medewerkers}

Vanaf de start worden medewerkers intensief betrokken bij het hele proces. Een van hen is Sylvia Moorer: 'Het is juist het loslaten van uurtje-factuurtje dat het zo fijn maakt. Ik kom graag overal en nergens.' Op het moment van het interview is ze bij Robert en Pascalle in Heerlerheide, die weliswaar zelfstandig wonen, maar wel de nodige begeleiding hebben omdat ze grote moeite hebben met de onderlinge communicatie en de contacten met verschillende instanties. Sylvia: 'Ik kom hier elke week wel even langs. Als het nodig is, kom ik vaker. Heb ik ergens anders een dringende zaak, dan bel ik even of het goed is dat ik een andere dag kom.' Robert: 'Sylvia of haar collega komt langs omdat wij het vragen of omdat een van hen vindt dat het nodig is. Het is niet meer gebonden aan vaste dagen en tijden. Dat is juist erg prettig.'

$\mathrm{Nu}$, na anderhalf jaar, is de coöperatie volop in beweging en het enthousiasme groeit met de dag. Het samenwerken met collega's van andere instellingen bevalt de meesten erg goed. Sylvia Moorer: 'Er is meer ruimte voor eigen inbreng en mensen laten inzien dat ze het zelf kunnen. Bij verbazingwekkend veel zaken hoef je iemands handje niet meer vast te houden. Cliënten kunnen veel meer zelf, je moet naar ze luisteren en ze het vertrouwen geven.'

Een goed voorbeeld hiervan is de 26-jarige autistische Jamail. Sinds enkele maanden woont hij, na jarenlang zware depressies te hebben gehad, op zichzelf in een flat in Heerlen. Jamail: 'Sylvia en haar collega geloven in mij en laten dat vooral ook zien. Ik mag veel zaken gewoon zelf regelen, en zij blijven op de achtergrond. Dat is fijn.'

Niet iedere medewerker vindt het prettig om volgens de vernieuwende werkwijze te werken. Vanuit de moederorganisatie zijn veel medewerkers gewend om vaak heel anders te werk te gaan. Daarom is het van belang om alle medewerkers erbij betrokken te houden. Dit betekent dat de coöperatie investeert in groeps- en individuele coaching van de medewerkers. Directeur Elvira van Bergen: 'Als we willen dat iedere burger volwaardig participeert, dan moeten we datzelfde voor onze medewerkers regelen. Alleen dan kunnen zij dat overbrengen in hun werk.'

\section{De nabije toekomst}

Inhoudelijk worden continu stappen gezet. 'Om te zorgen voor volwaardig burgerschap moeten we ontzorgen. Dat doen we door te voorkomen dat er problemen ontstaan. En als er problemen zijn, zorgen we ervoor dat mensen zo snel mogelijk weer een normaal leven hebben. Denk aan een huishouden, een partner, werk en zingeving in de vrije tijd. Zorg hoort in dat rijtje niet thuis.

Natuurlijk vindt niet iedereen onze werkwijze prettig. Sommige klanten willen er gewoon niks van weten, vooral het netwerk kan nogal eens hardnekkig zijn. Die willen gewoon dat jij komt om de zoon onder de douche te zetten. Wij kijken liever naar andere opties. We vragen of het niet mogelijk is om hun zoon te facetimen, zodat hij zelf naar de douche loopt. Daarnaast zijn we bezig om meer partners aan ons te binden. Denk aan werkgevers, relatiebemiddelingsbureaus - eigenlijk elke organisatie die staat voor volwaardig burgerschap zou een natuurlijke partner van ons moeten zijn.'

Voorheen werden de instanties op basis van uurtjefactuurtje gefinancierd. De gemeente Heerlen is met de komst van Heerlen STAND-BY! overgestapt op resultaatfinanciering. Elk jaar geeft de gemeente een zak met geld, waarvoor in ruil resultaten geboekt moeten worden. Heerlen STAND-BY! start per 2019 populatiebekostiging, een andere vorm van resultaatfinanciering. Per inwoner van de bevolking wordt een bedrag bepaald in relatie tot het resultaat dat bij die inwoner gehaald moet worden.

\section{Durven kiezen}

Directeur Elvira van Bergen kan zich voorstellen dat gemeenten dit concept graag kopiëren: 'Willen gemeenten de zorg echt betaalbaar houden en willen ze de kwaliteit van leven van hun inwoners echt vergroten, kies dan hiervoor. Maar je moet er als gemeente wel voor de volle $100 \%$ achter staan, ook als het moeilijk wordt. Heerlen heeft hiervoor durven kiezen en daar zijn we ontzettend dankbaar voor.'

Meer weten? www.heerlenstandby.nl 